\title{
Designing a Questionnaire Attempting to Discover Mentors' Feedback in the Professionalism of the Foreign Language Teacher Candidate
}

\author{
Ilknur Pekkanli \\ Uludag University, Bursa, Turkey \\ Email: ilknurp@uludag.edu.tr
}

\begin{abstract}
Teaching experiences are conducted in order to develop and sharpen the teacher candidates' abilities and skills in authentic teaching situations, they are also important collaborative processes between the teacher candidates and their mentors. Based on this situation, it is possible to state that the feedback given during the debriefing by mentors is one of the major constituents of these collaborating processes which apply elements of professionalism to the teacher candidates. The present study is an attempt to develop a scale/questionnaire familiar with the types of feedback that the teacher candidates receive from the cooperating school mentor teachers for their teaching experience performances. It is assumed that implementing such a scale can highlight mentor effectiveness because it is one of the preliminary means of investigating the teacher candidates' views of their mentors' assistance in their initial experiences.
\end{abstract}

Index Terms - mentoring, feedback, teacher candidate, reliability and validity

\section{INTRODUCTION}

Mentoring is a major component in teacher education/training programs. Teacher training programs have various courses in which, teacher candidates under the supervision of their mentors, are able to practice their teaching and reflect on their experiences for improving their teaching through field experiences. Prominent researchers claim that these types of field experiences are a valuable component of teacher preparation programs and are cited as the most important element of teacher training by graduates of teacher training programs (Guyton \& McIntyre, 1990, as cited in Capizzi et. al., 2010).

Mentoring is a collaborative effort between university teacher educators, school supervising teachers and pre-service teachers (He, 2009). Considering the point that teacher candidates and mentors (school teachers in the present case) are obliged to work co-operatively and face to face in educational settings, embeds a potential relational satisfaction directed by the verbal and non-verbal feedback communicated by the mentor. "Without adequate communication between mentor teachers and pre-service teachers regarding teaching expectations and beliefs, pre-service teachers leave teacher education programs ill-prepared to negotiate potential conflict between their beliefs and reality of teaching, leading to dissonance and resistance to adaptation (He, 2009, p.264)." In situations as such, communication and the quality of the feedback are important factors because the ways they are presented can determine its acceptance by the teacher candidate. It is claimed that "when supervisors deliver critical feedback to subordinates, it is hoped that the recipients will focus on the content of the message to gain information about ways of improving job performance. Previous work has shown that the attention given by the recipient to the content of the feedback, and acceptance of this content, determine whether the criticism will bring about corrective changes in behavior (I-Ilgen et. al., 1979; Kluger \& DeNisi, 1996, as cited in Leung et. al., 2001; p.1157)."

Teacher candidates need to be given constructive feedback; otherwise they would feel lost in their self reflections and evaluations of their teaching practices. The practicum school mentors with their positive feedback can assist the teacher candidates in the improving of professional teaching competency which they need for their future occupations. This point is addressed by Chastain, (1988) who states that "language teachers should always be sensitive to the types of feedback their students receive in class, and they should remember that the feedback should respond both to students' affective needs and cognitive needs (p. 48)." Otherwise, as research has shown, when there is negative feedback there can be a decrease in performance (Baron, 1993; Kluger \& DeNisi, 1996, as cited in Leung et. al., 2001; p.1157).”

Studies investigating mentoring have shown that teacher candidates have benefited considerably from mentoring experiences because mentoring provides teacher candidates and novice teachers support for developing their professional skills (Barkham, 2005; Clarke, 2004) and self-efficacy (Bandura, 1977). However, a literary review of mentoring shows that despite the point that "teacher candidate supervision has a longstanding history and tradition in teacher preparation programs (Capizzi et. al., 2010, p.3)," effective and thorough supervision remains a vital component 
of teacher training programs (Buck, Morsink,Griffin, \& Lenk, 1992; Darling-Hammond et al., 2005, as cited in Capizzi et. al., 2010)."

Supervision, mentoring and feedback are vital components not only for the teaching program but also for the teaching profession itself. Based on the argument of Devos (2010) it can be unanimously approved that mentoring as a vehicle for operationalising the professional standards plays an important role in the shaping of the profession over time and hence demanding greater scrutiny than has been applied to date. Therefore, the present study attempts to partially address the issue of mentors' feedback under scrutiny by investigating a case in Turkey.

In Turkey, state universities offering foreign language teacher training programs as a prerequisite for graduation have field experience courses. It is a necessity for teacher candidates to have experience in the teaching profession by taking up, in the final year of their education, two compulsory courses; one is based on practice at primary school and the other is at secondary school. However, to be able to take these courses it is a prerequisite to have passed the "special teaching methods" courses in the previous semesters. The first course which is "school experience" is in the first semester; it consists of one theoretical lesson at the university and four practicum lessons per week at a primary school. The second course "teaching practicum" which is obligatory in the last semester of the 4 year program consists of two theoretical lessons at the university, and six practicum lessons per week at the high school. These courses planning for the teacher candidates' hands on training and experiences are conducted at the schools where the practicum is experienced. Here, the university lecturers mentoring are conducted in partnership with the school classroom teachers. These classroom teachers have an important influence on the teacher candidates' professional development because "functioning as experts, mentors provide authentic, experiential learning opportunities through modeling. Through their actions and articulated ways of thinking, mentors teach new teachers effective skills and strategies (Saffold, 2005)."

In Turkey, in the traditional manner of the supervision of the teacher candidate, the qualified university mentor visits the candidate in various- most often limited periods. In order for the supervision to be more effective the teacher candidate is also actively and intensively supervised in longer periods by the classroom teacher. In the case of the present study the classroom teacher does most of the mentoring because s/he has to supervise the teacher candidate for at least six lessons per week. Therefore, in order to shed light upon the platform where mentoring shapes the future teachers' identity, the present study aims to investigate whether these teacher candidates, enrolled at an ELT department, receive constructive feedback from their practicum school teacher mentors in terms of; the ensuring of learner participation and interaction, the development of communicative competence in learners, the improvising of teaching methodology and current trends in language teaching, lesson planning, classroom management, and the familiarization of classroom tools and materials.

\section{METHOD}

\section{A. Measures}

In the primary stage of the process of scale development, after a thorough review of research relating to mentoring and feedback, a pool of items (approximately 53 items) were formed. Then with the assistance and guidance of three specialists in the field of teacher training, the construct and face validity of the items were debated. After this rigorous review of the items, again under the supervision of the specialists, ambiguous and overlapping items were filtered, decreasing the number of it items to a total of 22. Then, in order to diagnose further incomprehensible or irrelevant items, the scale was piloted to 15 teacher candidates. This piloting did not necessitate further differences to the scale and had shown this scale to have consistent measurement properties. At this stage, a scale with a series of 22 statements for each measure using a 5-point scale ranging from "strongly disagree" to "strongly agree" was formed.

All of the statements on the survey were based on a 5-point Likert scale, the end points being labeled as 1 "strongly disagree" to 5 "strongly agree". While the minimum score gained by the participants for the subscales Factor I and II was 8 , the maximum score was 40 . The minimum score for subscale factor III was 6 and the maximum was 30 . Also, statements 7, 14, 20, and 21 were reverse-coded.

\section{B. Participants and Procedure}

Participants were 68 ELT fourth/final year students (teacher candidates) enrolled at Uludag University, Faculty of Education, ELT Department in Bursa, Turkey. All of the participants achieved to pass the "school experience" and the "teaching practicum" courses.

Teacher candidates were administered a survey/questionnaire consisting of 22 items (see Appendix A). The teacher candidates answered the survey/questionnaire according to the feedback they gain from the mentors at the primary and high schools where their practicum courses were conducted.

\section{DATA ANALYSIS AND RESUlTS}

In order to analyze the structural reliability of the scale/questionnaire the total variance in the data was considered by utilizing Principal Component Analysis (PCA) (See Table 1). The factors were depicted according to the criteria stated by Büyüköztürk (2002): a) eigenvalues higher than 1 were considered, b) only items with factor loadings higher than 0.45 were inclusive to the factors, and c) screen test was utilized while determining the number of factors. Considering 
the criteria stated above, the initial component analysis of the survey revealed a 6 factor measurement. The variance of the total 6 factors was $67.71 \%$. Analysis of the factors displayed that the total variance of 3 factors were $50.72 \%$ $(35.40 \%, 9.18 \%$, and $6.14 \%)$ and the factor loadings of the remaining factors were less than 0.45 . Therefore, it was decided upon a 3 factor scale and variance maximizing rotation was applied. This analysis revealed that 20 of the 22 items on the scale had factor loadings which were higher than. 45 and that the contribution of the 3 factors to the total variance of $51.81 \%$ was $22.31 \%, 19.65 \%$, and $\% 9.85 \%$.

While the original scale had 22 items, the statistical analysis has only 20 items. The removal of items 11 (I can overcome, on my own, the unexpected difficulties that arise in the classroom) and 22 (While giving feedback my mentor gives me time to think and respond) enhanced internal consistency and resulted in an increase in Cronbach's alpha (See Table 1). The Cronbach's alpha reliability coefficient for the 3 factors were as follows: Factor I - 0.83 (8 items: $2,6,8,9,10,13,16$, and 17), Factor II - 0.74 (8 items: 1, 3, 5, 12, 15, 18, 19, and 20), and Factor III - 0.57 (4 items: $4,7,14$, and 21 ).

Then, variance maximizing (varimax) rotation was applied with 3 factor solution analysis and this analysis revealed the point that 20 of the 22 items displayed factor loadings higher than .47 within the 3 factors depicted. The reliable 20 items loaded to the 3 factors which were sub-labeled as; Factor I- "mentor effectiveness," Factor II-"mentor openness (criticism and sharing)," and Factor III "mentor support."

TABLE 1

MENTOR SURVEY FACTOR ANALYSIS (PRINCIPAL COMPONENT ANALYSIS)

\begin{tabular}{|c|c|c|c|}
\hline Item Number & Factor 1 & Factor 2 & Factor 3 \\
\hline Item 2 & ,601 & & \\
\hline Item 6 & ,678 & & \\
\hline Item 8 & ,588 & & \\
\hline Item 9 & ,681 & & \\
\hline Item 10 & ,669 & & \\
\hline Item 13 & ,472 & & \\
\hline Item 16 & ,805 & & \\
\hline Item 17 & ,590 & & \\
\hline Item 1 & & ,587 & \\
\hline Item 3 & & ,662 & \\
\hline Item 5 & & ,585 & \\
\hline Item 12 & & ,616 & \\
\hline Item 15 & & ,661 & \\
\hline Item 18 & & ,525 & \\
\hline Item 19 & & ,481 & \\
\hline Item 20 & & ,653 & \\
\hline Item 4 & & & ,527 \\
\hline Item 7 & & & ,793 \\
\hline Item 14 & & & ,516 \\
\hline Item 21 & & & ,518 \\
\hline Variance & $\% 22.30$ & $\% 19.65$ & $\% 9.85$ \\
\hline Eigenvalues & 4.68 & 4.12 & 2.07 \\
\hline Alpha & .83 & .74 & .57 \\
\hline
\end{tabular}

\section{DiSCUSSION AND CONCLUSION}

Statistical analysis of the scale displays that the feedbacks are mainly based on the following dimensions; the ensuring of learner participation and interaction, the development of communicative competence in learners, the improvising of teaching methodology and current trends in language teaching, lesson planning, classroom management, and the familiarization of classroom tools and materials. Within this context, it can be assumed that the scale has reached the aim forming a scale depicting the teacher candidates' views on the types and effectiveness of feedback they receive from their mentors regarding their performances.

Policies relating to teacher mentoring programs are established. For example, in Turkey, new graduates who want to seek full registration as a teacher in public schools must take the KPSS examination (government employee qualifying examination) and gain a certain score in order to be appointed. After being appointed the novice teacher is placed under the supervision of an experienced teacher in her/his first year of employment. In Australia, under the Victorian 'Induction and Mentoring of Beginning Teachers' policy, new graduates (if employed in a school) are required to participate in the 'Provisionally Registered Teachers Program' where they are mentored for 12 months and at the end of this period they have to present evidence of their competence which must meet the Standards of Professional Practice (Devos 2010). As can be seen from the examples, the novice teacher even after graduation has a mentor and is supervised to see whether they meet national standards.

"Mentoring for teachers' professional development has been touted as the pinnacle of good professional practice, especially in guiding beginning teachers in their first year of full-time employment (Guarino, Santibanez, Daley, \& Brewer, 2004, as cited in Long, 2009). Another important finding is that of Bobek (2002) who has pointed out that 
building relationships, including mentoring programs and support, is one the five major reasons for teachers to continue to work in the field of teaching. Also, as Long (2009) demonstrates, mentoring is such a factor that at times when it is not conducted professionally it can contribute to reasons for beginning teachers to leave the profession. Furthermore, as the Alliance for Excellence in Education Report (2005) into teacher attrition in the USA found 'new teachers are given little professional support, feedback, or demonstration of what it takes to help their students succeed' (p.2, as cited in Long, 2009, p.319). When there is insufficient mentoring, novice or candidate teachers face the challenge of 'sink or swim' with no-one to throw them a rescue float (Smith \& Ingersoll, 2004). Then, it can be claimed that critical observations and constructive feedback of the mentoring processes conducted before and after graduation are imperative for the preparation of the teacher to be qualified and effective in their professions.

In regard to the relationship between professionalization of teaching and mentoring, in order for teacher candidates and mentors to reach policies meeting the standards of becoming an effective teacher, the comments in closing can be regarded as a proposal for further research in this area.

\section{APPENDIX A}

Questionnaire -Mentor Feedback (to be filled in by teacher candidates)

$$
1=\text { Strongly disagree } \quad 2=\text { Mildly disagree } \quad 3=\text { Neutral } \quad 4=\text { Mildly agree } 5=\text { Strongly agree }
$$

\begin{tabular}{|c|c|c|c|c|c|}
\hline (Please tick one box only for each statement) & 1 & 2 & 3 & 4 & 5 \\
\hline \multicolumn{6}{|l|}{ 1- My mentor respects and is tolerant of the individual differences of the teacher trainees. } \\
\hline \multicolumn{6}{|l|}{ 2- My mentor acknowledges and works through conflicts openly with me. } \\
\hline \multicolumn{6}{|l|}{ 3- My teacher works for consensus on decisions with me. } \\
\hline \multicolumn{6}{|l|}{ 5- My mentor trusts, supports and has genuine concern for my development. } \\
\hline \multicolumn{6}{|l|}{ 6- My mentor checks for my comprehension of the verbal messages. } \\
\hline \multicolumn{6}{|l|}{ 9- My mentor assists me in developing my personal skills in planning. } \\
\hline \multicolumn{6}{|l|}{ 10- When giving me feedback my teacher first praises me. } \\
\hline \multicolumn{6}{|l|}{ 11- I can overcome, on my own, the unexpected difficulties that arise in the classroom. } \\
\hline \multicolumn{6}{|l|}{ 12- My mentor encourages my usage of various classroom tools and materials. } \\
\hline \multicolumn{6}{|l|}{ 13- Before giving feedback my mentor asks me to self-assess first. } \\
\hline \multicolumn{6}{|l|}{ 18- My mentor develops my awareness of the tools and material which can be used in the activities. } \\
\hline \multicolumn{6}{|l|}{ 19- When giving feedback my mentor comments on specific behaviors and achievements. } \\
\hline \multicolumn{6}{|l|}{ 20- When giving feedback my mentor gives me general comments. } \\
\hline \multicolumn{6}{|l|}{ 21- While I am getting feedback from my mentor, I feel accused of my teaching practice. } \\
\hline 22- While giving feedback my mentor gives me time to think and respond. & & & & & \\
\hline
\end{tabular}

\section{REFERENCES}

[1] Bandura, A. (1977). Self-Efficacy: Toward a unifying theory of behavior change. Psychological Review, 84, 191-215.

[2] Bobek, B. L. (2002). Teacher Resiliency: A key to career longevity. The Clearing House, 75 (4), 202-205.

[3] Barkham, J. (2005). Reflections and interpretations on life in academia: a mentee speaks. Mentoring and Tutoring, 13 (2), 331 344.

[4] Büyüköztürk, Ş. (2002). Sosyal Bilimler Için Veri Analizi El Kitabı. Pegem A Yayıncılık. Ankara, Turkey.

[5] Cappizi, M. A., J.H. Wehby, \& K. N: Sandmel. (2010) Enhancing Mentoring of Teacher Candidates Through Consultative Feedback of Instructional Delivery. Teacher Education and Special Education. August 2010; 33 (3), pp. 191-212.

[6] Chastain, K. (1988). Developing Second Language Skills. Harcourt Brace Jovanovich, Inc. Florida, U.S.A.

[7] Clarke, M. (2004). Reconceptualizing mentoring: reflections by an early career researcher. Issues in Educational Research, 14 (2), 121-143.

[8] Devos, A. (2010). New teachers, mentoring and the formation of professional identities, Teaching and Teacher Education. Vol. 26, pp. 1219-1223.

[9] He, Y. (2009). Strength-based mentoring in pre-service teacher education: a literature review. Mentoring \& Tutoring: Partnership in Learning. Vol. 17, No. 3, Aug. 2009, pp. 263-275.

[10] Leung, K., S. Su \& M. W. Morris. (2001). When Is Criticism Not Constructive? The roles of fairness perceptions and dispositional attributions in employee acceptance of critical supervisory feedback. Human Relations, Vol. 54 (9) ps. $1155-1187$. Sage Pub. New Delhi.

[11] Long, J. (2009). Assisting beginning teachers and school communities to grow through extended and collaborative mentoring experiences. Mentoring \& Tutoring: Partnership in Learning. Vol. 17, No. 4, Nov. 2009, pp. 317-327.

[12] Saffold, F. (2005). Increasing self-efficacy through mentoring. Academic Exchange Quarterly. Winter. Rapid Intellect Group, Inc. Winter 2005. Volume 9, Issue 4.

[13] Smith, T., \& Ingersoll, R. (2004). What are the effects of induction and mentoring on beginning teacher turnover? American Educational Research Journal, 41 (3), 681-715. 
Ilknur Pekkanli graduated from ELT Department, Faculty of Education, Uludag University in 1990. She has been working at this department as an instructor since 1990. In 1996, she gained her M.A. from Department of Translation and Interpretation, Bosphoros University and received her Ph.D. from Institute of Social Sciences, ELT Department, Anadolu University in 2003. 